\title{
ANALISIS USAHATANI PADI ORGANIK DI KECAMATAN NGUNTORONADI, KABUPATEN WONOGIRI
}

\author{
Titania Fitriana Dewi' ${ }^{1)}$ Joko Sutrisno2), Tria Rosana Dewi3) \\ 1) Fakultas Pertanian, Jurusan Agribisnis, Universitas Islam Batik, JI.KH Agus Salim No.10, Jawa Tengah \\ 57147, Telp (0271) 714751, email: titaniafitriana@gmail.com \\ 2) Fakultas Pertanian, Jurusan Agribisnis, Universitas Sebelas Maret Surakarta, Jl. Ir. Sutami no 32A Telp \\ (0271) 646994._, email: jokosutrisno@staff.uns.ac.id \\ 3)Fakultas Pertanian, Jurusan Agribisnis, Universitas Islam Batik, Jl.KH Agus Salim No.10, Jawa Tengah \\ 57147, Telp (0271) 714751, email: triardewi@yahoo.co.id
}

\begin{abstract}
Abstrak
Tujuan dari penelitian ini adalah untuk mengetahui dan membandingkan produtivitas, pendapatan, efisiensi dan kemanfaatan usahatani padi organik varietas Mentik dengan usahatani padi organik varietas IR 64 di Kecamatan Nguntoronadi, Kabupaten Wonogiri. Penelitian ini dilaksanakan dengan menggunakan metode teknik purposive sampling. Lokasi penelitian dan pengambilan sampel responden dipilih secara sengaja. Hasil analisis menunjukkan bahwa usahatani padi organik varietas Mentik memiliki nilai produktivitas sebesar $4.589,59 \mathrm{Kg} / \mathrm{Ha} / \mathrm{MT}$ berbeda nyata dengan produktivitas usahatani pada organik varietas IR 64 yaitu 4.239,59 $\mathrm{Kg} / \mathrm{Ha} / \mathrm{MT}$. Pendapatan yang diperoleh dari usahatani padi organik varietas Mentik adalah 21.184.250,03 $\mathrm{Rp} / \mathrm{Ha} / \mathrm{MT}$ berbeda nyata dengan pendapatan yang diperoleh dari usahatani padi organik varietas IR 64 yaitu 16.086.779,82 Rp/Ha/MT. Efisiensi usahatani padi organik varietas Mentik berbeda nyata dengan usahatani padi organik varietas IR 64 , usahatani padi organik varietas Mentik mempunyai efisiensi $R / C$ ratio sebesar 2,93 , sedangkan pada usahatani padi organik varietas IR 64 yatitu $R / C$ ratio sebesar 2,40 . Usahatani padi organik varietas Mentik mempunyai kemanfaatan yang lebih tinggi dibandingkan dengan padi organik varietas IR 64 dengan nilai incremental $\mathrm{B} / \mathrm{C}$ ratio 8,67 .
\end{abstract}

Kata Kunci : efisiensi, padi organik, pendapatan, produktivitas, usahatani

\section{Abstract}

The purpose of this study was to determine and compare the productivity, income, efficiency and benefits of the Mentik variety organic rice farming with IR 64 variety in Nguntoronadi District, Wonogiri Regency. This research was conducted using a purposive sampling method as a side technique. The location of the study and the sampling of respondents were chosen deliberately. The results of the analysis showed that the Mentik variety organic rice farming had a productivity value of $4.589 .59 \mathrm{Kg} / \mathrm{Ha} / \mathrm{MT}$ which was significantly different from the farming productivity of the organic variety IR 64, namely $4.239 .59 \mathrm{Kg} / \mathrm{Ha} / \mathrm{MT}$. The income obtained from organic rice farming of Mentik variety is $21,184,250.03 \mathrm{Rp} / \mathrm{Ha} / \mathrm{MT}$, which is significantly different from the income obtained from organic rice farming of IR 64 variety, which is 16,086,779.82 Rp / Ha / MT. The efficiency of organic rice farming of Mentik variety was significantly different from that of IR 64 variety, organic rice farming of Mentik variety had an efficiency of $R / C$ ratio of 2.93, while in organic rice farming of IR 64 variety, that was, $R / C$ ratio of 2.40. The Mentik variety organic rice farming has higher benefits compared to the IR 64 variety with an incremental $B / C$ ratio of 8.67 .

Keywords: efficiency, organic rice, income, productivity, farming

\section{PENDAHULUAN}

Pertanian merupakan salah satu sektor yang sangat dominan dalam pendapatan masyarakat di Indonesia karena mayoritas penduduk Indonesia berkerja sebagai petani. Namun, produktivitas pertanian masih jauh dari harapan. Salah satu faktor penyebab kurangnya produktivitas pertanian adalah sumber daya manusia yang masih rendah. Pembangunan pertanian diarahkan untuk meningkatkan produksi pertanian guna 
memenuhi kebutuhan pangan dan kebutuhan industri. dalam negeri, meningkatkan ekspor, meningkatkan pendapatan petani, memperluas kesempatan kerja dan mendorong pemerataan kesempatan berusaha (Soekartawi, 2001).

Ciri utama pertanian organik adalah penggunaan varietas lokal yang alami diikuti penggunaan pupuk dan pestisida organik. Ditinjau dari segi kesehatan, produk organik aman dikonsumsi manusia karena bebas dari residu zat berbahaya (Andoko, 2002).

Pertanian organik makin banyak diterapkan pada beberapa komoditi pertanian, salah satunya adalah padi sebagai komoditi penghasil beras dan sebagai bahan makanan pokok sebagian besar penduduk Indonesia. Keunggulan beras organik adalah sehat, dengan kandungan gizi atau vitamin yang tinggi karena tidak menghilangkan lapisan kulit ari secara menyeluruh 2 sehingga beras ini tidak tampak mengkilap seperti beras pada umumnya. Beras lebih enak dan memiliki rasa alami atau pulen, lebih tahan lama dan tidak basi serta memilki kandungan serat dan nutrisi lebih baik. Selain itu, manfaat beras organik bagi lingkungan, diantaranya sistem produksi sangat ramah lingkungan sehingga tidak merusak lingkungan, tidak mencemari lingkungan dengan bahan kimia sintetik dan meningkatkan produktivitas ekosistem pertanian secara alami, serta menciptakan keseimbangan ekosistem terjaga dan berkelanjutan (Sutanto, 2002).

Kesadaran masyarakat pada produk yang sehat menyebabkan permintaan akan beras organik juga semakin meningkat sehingga petani untuk mengusahakan dan menanam padi organik semakin meningkat. Perkembangan produksi padi dengan sistem organik memang diperlukan karena padi organik pada proses produksinya tidak menggunakan bahan anorganik. Salah satunya di Desa Beji Kecamatan Nguntoronadi Kabupaten Wonogiri yang telah menerapkan sistem pertanian organik dan sudah tersertifikasi. Nguntoronadi adalah sebuah Kecamatan di Kabupaten Wonogiri, Jawa Tengah. Kecamatan ini di sebelah barat berbatasan dengan Waduk Gajah Mungkur.

Kecamatan Nguntoronadi memiliki produktivitas $5,24 \mathrm{Ton} / \mathrm{Ha}$ dengan luas panen 2,635.74 Ha dan produksi 13,803.49 Ton. Luas Wilayah Kecamatan Nguntoronadi 8.040,5175 ha Wonogiri. Wilayah administrasi terdiri dari 2 kelurahan, 9 desa, 72 RW dan 188 RT. Jarak $28 \mathrm{Km}$ sebelah selatan Kota Wonogiri. Ketinggian $150 \mathrm{~m}$ dari 4 permukaan air laut (BPS, 2018).

Masyarakat di Desa Beji membudidayakan padi organik melalui sebuah gabungan kelompok tani yaitu gapoktan Beji Makmur. Beberapa varietas padi organik yang diantaranya adalah varietas IR 64, Mentik dan Beras Merah. Varietas yang banyak diminati oleh masyarakat pada umumnya yaitu varietas IR 64 dan Mentik, sehingga petani di daerah tersebut banyak yang membudidayakannya oleh karena itu dipilih varietas Mentik dan IR 64. Tujuan dari penelitian ini adalah sebagai berikut mengetahui dan membandingkan produktivitas usahatani padi organik varietas Mentik dengan usahat tani padi organik varietas IR 64, membandingkan pendapatan usahatani padi organik varietas Mentik dengan usahatani padi organik varietas IR 64, membandingkan efisiensi usahatani padi organik varietas Mentik dengan usahatani padi organik varietas IR 64 serta membandingkan kemanfaatan dari usahatani padi organik varietas Mentik dengan usahatani padi organik varietas IR 64.

\section{BAHAN DAN METODE}

Metode dasar yang digunakan dalam penelitian ini adalah metode deskriptif yaitu penelitian yang bermaksud untuk membuat pencandraan (deskripsi) mengenai situasisituasi atau kejadian-kejadian. Data yang ada mula-mula disusun, dijelaskan kemudian dianalisis, karena itu metode ini sering pula disebut metode deskriptif analitik (Suryabrata, 2010).

Penelitian ini dilakukan di Desa Beji Kecamatan Nguntoronadi Kabupaten Wonogiri dengan pertimbangan bahwa di lokasi tersebut sudah tersertifikasi organik. Pengambilan petani sampel secara sengaja berdasarkan hasil survey di Desa Beji Kecamatan Nguntoronadi. Petani sampel yang digunakan yaitu 20 petani padi organik varietas Mentik dan 20 petani padi organik varietas IR 64 dari anggota gabungan kelompok tani (gapoktan) Beji Makmur.

Metode analisis data untuk mengetahui pendapatan usahatani padi organik, terlebih dahulu harus mengetahui besarnya biaya 
mengusahakan dan penerimaan usahatani padi organik. Untuk mengetahui efisiensi usahatani padi organik yaitu perbandingan antara penerimaan dengan biaya. Sedangkan untuk menilai kemanfaatan usahatani padi organik dengan perbandingan antara selisih penerimaaan dengan biaya mengusahakan. Kemudian pengujian hipotesis yang diajukan, dilakukan uji komparasi dengan menggunakan uji t (t-test).

\section{HASIL DAN PEMBAHASAN}

Usahatani padi organik yang dilakukan di Desa Beji, Kecamatan Nguntoronadi Kabupaten Wonogiri merupakan usahatani yang membudidayakan tanaman padi dengan menggunakan pupuk organik baik padat maupun cair. Saat masa peralihan dari usahatani anorganik menjadi usahatani organik, produksi akan mengalami penurunan. Akan tetapi, produksi padi yang telah melakukan usahatani organik mengalami peningkatan, tanaman lebih tahan terhadap serangan hama dan biaya-biaya usahatani yang digunakan bisa lebih rendah.

Biaya penggunaan tenaga kerja pada usahatani padi organik varietas Mentik ratarata sebesar Rp. 4.670.124,99 / $\mathrm{Ha} / \mathrm{MT}$, sedangkan rata-rata biaya tenaga kerja pada usahatani padi organik varietas IR 64 lebih tinggi yaitu sebesar Rp. 5.504.166,68 / Ha/MT. Upah tenaga kerja yang berlaku di daerah penelitian secara umum untuk tenaga kerja pria adalah Rp. $60.000,00$ / orang/ hari kerja, sedangkan untuk tenaga kerja wanita adalah Rp. 50.000,00 / oraang/ hari kerja. Beberapa kegiatan usahatani seperti pengairan dan pengendalian hama dilakukan oleh tenaga kerja sendiri dan kegiatannya juga tidak rutin, sedangkan pengendalian hama hanya dilakukan pengamatan, jika terdapat gejala hama dan penyakit tanaman maka dilakukan penyemprotan dengan pestisida nabati. Penggunaan tenaga kerja pada kegiatan pemanenan biasanya menggunakan sistem borongan. Kegiatan pengolahan tanah pada umumnya menggunakan traktor untuk membajak tanah. Adanya perbedaan rata-rata biaya sarana produksi dan rata-rata biaya tenaga kerja menyebabkan rata-rata biaya mengusahakan atau biaya usahatani dari usahatani tersebut juga berbeda. Rata-rata biaya usahatani padi organik varietas Mentik adalah sebesar Rp. 10.942.833,3 /Ha/MT, lebih rendah dibandingkan dengan rata-rata biaya usahatanui padi organik varietas IR 64 sebesar Rp. 11.470.511,84/Ha/MT.

Produktivitas varietas Mentik dan IR 64 besarnya berbeda nyata karena potensi dan karakteristiknya antara varietas Mentik dan IR 64 tidak sama. Rata-rata produktivitas usahatani padi organik varietas Mentik adalah $4.589,59 \mathrm{Kg} / \mathrm{Ha} / \mathrm{MT}$, berbeda dengan rata-rata produktivitas padi organic varietas IR 64 yaitu sebesar 4.239,59 /Kg/Ha/MT.

Rata-rata harga gabah padi organik varietas Mentik adalah Rp. $7.000 / \mathrm{Kg}$, tidak jauh berbeda dengan rata-rata harga gabah padi organik varietas IR 64 , yaitu $R p .6 .500$ $/ \mathrm{Kg}$. Hal itu dapat terjadi karena mayoritas petani menjual hasil panennya ke penebas atau tengkulak dan memang harga jual varietas Mentik lebih tinggi. Petani lebih suka menjual ke tengkulak atau penebas karena petani ingin segera menerima uang untuk memenuhi kebutuhan hidup petani. Selain itu, dengan menjual hasil panen ke tengkulak atau penebas petani tidak kesulitan untuk merawat hasil panen dan dalam penentuan tempat penjualannya. Sistem penjualan seperti ini sebenarnya tidak menguntungkan petani karena sistem penjualan ini memiliki beberapa resiko antara lain jika petani kurang teliti atau kurang cermat, maka penebas dapat menipu petani dengan menurunkan harga jual gabah per kilogram atau menurunkan berat gabah hasil panen. Selain itu, rata-rata harga yang tidak jauh berbeda yang diperoleh petani juga dikarenakan adanya kesepakatan antara penebas dan tengkulak tentang harga gabah yang akan tengkulak tawarkan kepada petani, sehingga petani tidak mempunyai banyak pilihan untuk memilih harga yang tertinggi.

Besarnya produktivitas padi dan harga gabah hasil panen baik pada usahatani padi organik varietas Mentik maupun usahatani padi organik varietas IR 64 akan mempengaruhi besarnya penerimaan. Penerimaan usahatani padi organik varietas Mentik yaitu Rp. 32.127.083,33 / $\mathrm{Ha} / \mathrm{MT}$ dan penerimaan ushatani padi organik varietas IR $64 \mathrm{Rp}$. 27.557.291,66 /Ha/MT.

Pendapatan usahatani dipengaruhi oleh penerimaan yang diterima petani dan biaya mengusahakan yang dikeluarkan oleh petani. Namun pendapatan usahatani secara tidak langsung juga dipengaruhi oleh penggunaan sarana produksi. Penggunaan sarana produksi 
akan mempengaruhi besar kecilnya biaya usahatani, dan penggunaan sarana produksi akan berpengaruh pada hasil produksi yang kemudian berpengaruh pada penerimaan. Hasil analisis, menunjukan bahwa rata-rata pendapatan usahatani padi organik varietas Mentik Rp. 21.184.250,03 / Ha/MT, berbeda nyata dengan rata-rata pendapatan usahatani padi organik varietas IR 64 yaitu $R p$. 16.086.779,82 /Ha/MT.

Menurut Soekartawi (2001) pendapatan petani yang besar belum tentu memberikan efisiensi yang tinggi pula. Tentu saja efisiensi ini berbeda antara usahatani satu dengan yang lain. Menurut Soekartawi (1993) didalam kegiatan usahatani seorang petani dituntut untuk bekerja secara efisien dalam mengalokasikan faktor-faktor produksi yang dimilikinya agar diperoleh kombinasi optimal.

Nilai efisiensi usahatani padi organik varietas Mentik dan usahatani padi organik varietas IR 64 dapat dihitung dengan menggunakan rumus $\mathrm{R} / \mathrm{C}$ ratio. Berdasarkan hasil analisis yang telah dilakukan, diperoleh hasil bahwa nilai $\mathrm{R} / \mathrm{C}$ ratio usahatani padi organik varietas Mentik lebih tinggi daripada nilai $R / C$ ratio usahatani padi organik varietas IR 64 yang besarnya 2,93 dan 2,40. Kedua usahatani tersebut telah efisien karena nilai $\mathrm{R} / \mathrm{C}$ rationya lebih dari satu. Berdasarkan hal tersebut maka dapat dikatakan bahwa usahatani padi organik varietas Mentik lebih efisien dalam pengelolaan usahataninya, dikarenakan jumlah biaya yang dikeluarkan pada usahatani padi organik varietas Mentik memiliki selisih yang lebih besar dengan pendapatannya dibandingkan selisih biaya usahatani padi organik varietas IR 64 dengan pendapatannya.

Menurut Adi Prayoga, 2010, peningkatan efisiensi teknis melalui peningkatan frekuensi kegiatan penyuluhan tentang usahatani padi organik perlu dilakukan secara kontinyu oleh dinas atau instansi terkait. Hal ini dimaksudkan agar petani dapat lebih baik dalam mengelola usahatani padi organik sehingga efisiensi teknis yang dicapai sekarang dapat ditingkatkan.

Nilai Incremental $\mathrm{B} / \mathrm{C}$ ratio digunakan untuk menunjukkan kemanfaatan secara ekonomi usahatani (Jumna, 2017). Berdasarkan hasil penelitian, nilai incremental $\mathrm{B} / \mathrm{C}$ ratio usahatani padi organik varietas Mentik dan usahatani padi organik varietas IR
64 adalah sebesar 8,67. Nilai incremental B/C ratio tersebut lebih besar dari satu. Hal ini berarti bahwa usahatani padi organik varietas Mentik lebih memberikan tambahan manfaat kepada petani dibandingkan dengan varietas IR 64.

\section{SIMPULAN}

1. Produktivitas usahatani padi organik varietas Mentik sebesar 4.589,59 $\mathrm{Kg} / \mathrm{Ha} / \mathrm{MT}$ berbeda nyata dengan produktivitas usahatani padi organik varietas IR 64 yaitu 4.239,59 $/ \mathrm{Kg} / \mathrm{Ha} / \mathrm{MT}$.

2. Pendapatan yang diperoleh dari usahatani padi organik varietas Mentik adalah Rp. 21.184.250,03 / Ha/MT berbeda nyata dengan pendapatan yang diperoleh dari usahatani padi organik varietas IR 64 yaitu $R p$. 16.086.779,82 / $\mathrm{Ha} / \mathrm{MT}$.

3. Efisiensi usahatani padi organik varietas Mentik berbeda nyata dengan usahatani padi organik varietas IR 64 . Usahatani padi organik varietas Mentik mempunyai efisiensi $\mathrm{R} / \mathrm{C}$ ratio sebsar 2,93 sedangkan pada usahatani padi organik varietas IR 64 yaitu $R / C$ ratio sebesar 2,40

4. Usahatani padi organik varietas Mentik mempunyai kemanfaatan yang lebih tinggi dibandingkan usahatani padi organik varietas IR 64 dengan nilai incremental $\mathrm{B} / \mathrm{C}$ ratio sebesar 8,67 .

\section{DAFTAR PUSTAKA}

Adi Prayoga. 2010. Produktivitas Dan Efisiensi Teknis Usahatani Padi Organik Lahan Sawah Di Desa Sukorejo dan Jambeyan, Kecamatan Sambirejo, Kabupaten Sragen. Jurnal Agro Ekonoml

Andoko A. 2002. Budidaya Padi Secara Organik. Jakarta : Penebar Swadaya.

Badan Pusat Statistik Wonogiri. 2018. Luas Panen, Produksi dan Produktivitas Padi Menurut Kecamatan di Kabupaten Wonogiri. Alamat https://wonogirikab.bps.go.id/statictable/ 2019/11/19/406/luas-panenproduksidan-produktivitas-padi-menurutkecamatan-di-kabupatenwonogiri- 
Dewi, et al. 2021

2018.html Diakses pada 9 Mei 2020 pukul 10.40 WIB.

Jumna, B. (2017). "Strategi Pengembangan Usahatani Dalam Upaya Peningkatan Produksi Padi Organik". Economics Development Analysis Journal, 4(3), 233-241.

Soekartawi. 1993. Manajemen Pemasaran Dalam Bisnis Modern. Jakarta: Pustaka Harapan.
Soekartawi. 2001. Pengantar Agroindustri. Jakarta : PT. Raja Grafindo Persada

Suryabrata. 2010. Metodologi Penelitian. Jakarta: Rajawali Pers

Sutanto, R., 2002. Penerapan Pertanian Organik. Yogyakarta: Kanisius. 
Agrisaintifika

Jurnal Ilmu-Ilmu Pertanian

Vol. 5, No. 1, 2021

Dewi, et al. 2021

\section{LAMPIRAN}

\section{Karakteristik Petani Sampel}

Tabel 1. Karakteristik Petani Sampel Usahatani Padi Organik Desa Beji Kecamatan Nguntoronadi Kabupaten Wonogiri

\begin{tabular}{clcc}
\hline \hline \multirow{2}{*}{ No } & \multicolumn{1}{c}{ Uraian } & \multirow{2}{*}{ Varietas Mentik } & \multirow{2}{*}{ Varietas IR 64 } \\
& & 20 & 20 \\
\hline 1 & Jumlah petani responden (orang) & 54,15 & 54,5 \\
2 & Rata-rata umur petani (tahun) & 8,8 & 8,3 \\
3 & Rata-rata pendidikan petani (tahun) & 3,6 & 3,5 \\
4 & Rata-rata jumlah anggota keluarga (orang) & 25,95 & 20,65 \\
5 & Rata-rata pengalaman dalam usahatani padi sawah (tahun) & 5,35 & 5,45 \\
6 & Rata-rata pengalaman dalam usahatani padi organik (tahun) & 0,24 & 0,24 \\
7 & Rata-rata luas lahan sawah yan digarap (Ha) & \\
\hline \hline
\end{tabular}

Sumber : Data yang telah diolah, 2020

\section{Penggunaan Sarana Produksi}

Tabel 2. Rata-Rata Penggunaan Sarana Produksi Usahatani Padi Organik Varietas Mentik Dan Varietas IR 64 Desa Beji Kecamatan Nguntoronadi Kabupaten Wonogiri

\begin{tabular}{cccccc}
\hline \multirow{2}{*}{ No } & \multirow{2}{*}{ Uraian } & \multicolumn{2}{c}{ Varietas Mentik } & \multicolumn{2}{c}{ Varietas IR 64 } \\
\cline { 3 - 6 } & & Per UT & Per Ha & Per UT & Per Ha \\
\hline 1 & Benih (Kg) & 7,37 & 30,708 & 9,07 & 37,791 \\
2 & Pupuk & & & & \\
& a. Organik (Kg) & 1.040 & $4.333,3$ & 1.300 & $5.416,6$ \\
& b. POC (liter) & 2,5 & 10,416 & 2,5 & 10,416 \\
\multirow{2}{*}{3} & Pestisida (liter) & 2,1 & & & \\
& a. Hayati & 0,61 & 2,75 & 02 & 8,42 \\
& b. Tricoderma & 0,44 & 0,70 & 4,04 \\
& c. Corine B & 0,48 & 2 & & 2,92 \\
\hline \hline
\end{tabular}

Sumber : Data yang telah diolah, 2020

\section{Penggunaan Tenaga Kerja}

Tabel 3. Rata-Rata Penggunaan Tenaga Kerja Pada Usahatani Padi Organik Varietas Mentik Dan IR 64 Desa Beji Kecamatan Nguntoronadi Kabupaten Wonogiri

\begin{tabular}{clcccccc}
\hline \multirow{2}{*}{ No } & \multirow{2}{*}{ Uraian } & \multicolumn{3}{c}{ Varietas Mentik } & \multicolumn{3}{c}{ Varietas IR 64 } \\
\cline { 2 - 7 } & & Per UT & Per Ha & $\% \mathrm{Ha}$ & Per UT & Per Ha & $\% \mathrm{Ha}$ \\
\hline 1 & Pembajak & 1,1 & 4,58 & 6,87 & 1,3 & 5,41 & 8,04 \\
2 & Pencangkulan & 2 & 8,33 & 12,49 & 2 & 8,33 & 12,39 \\
3 & Penggaruan & 1,05 & 4,37 & 6,56 & 1,05 & 4,37 & 6,49 \\
4 & Persemaian & 1 & 4,17 & 6,25 & 1 & 4,17 & 6,21 \\
5 & Penanaman & 2,45 & 10,21 & 15,32 & 2,6 & 10,83 & 16,10 \\
6 & Pemupukan & 1,15 & 4,79 & 7,18 & 1 & 4,17 & 6,21 \\
7 & Penyiangan & 2 & 8,33 & 12,49 & 2 & 8,33 & 12,39 \\
8 & Pengendalian Hama & 1 & 4,17 & 6,25 & 1 & 4,17 & 6,21 \\
9 & Pemanenan & 2,45 & 10,21 & 15,32 & 2,65 & 11,04 & 16,41 \\
10 & Pengangkutan & 1,8 & 7,5 & 11,25 & 1,55 & 6,46 & 9,61 \\
& Jumlah & $\mathbf{1 6}$ & $\mathbf{6 6 , 6 6}$ & $\mathbf{1 0 0}$ & $\mathbf{1 6 , 1 5}$ & $\mathbf{6 7 , 2 8}$ & $\mathbf{1 0 0}$ \\
\hline \hline
\end{tabular}

Sumber : Data yang telah diolah, 2020 
Agrisaintifika

Jurnal Ilmu-Ilmu Pertanian

Vol. 5, No. 1, 2021

Dewi, et al. 2021

4. Biaya Usahatani

Tabel 4. Rata-Rata Biaya Sarana Produksi Usahatani Padi Organik Varietas Mentik Dan Varietas IR 64 Desa Beji Kecamatan Nguntoronadi Kabupaten Wonogiri

\begin{tabular}{llllllll}
\hline \hline \multirow{2}{*}{ No } & \multicolumn{2}{c}{ Uraian } & \multicolumn{3}{c}{ Varietas Mentik } & \multicolumn{3}{c}{ Varietas IR 64 } \\
\cline { 2 - 7 } & \multicolumn{1}{c}{ Per UT } & Per Ha & $\%$ & Per UT & Per Ha & $\%$ \\
\hline 1 & Benih (Rp) & $73.750,00$ & $307.291,66$ & 5,27 & $90.750,00$ & $378.125,00$ & 7,10 \\
2 & Pupuk (Rp) & & & & & & \\
& a. Organik & $1.040 .000,00$ & $4.333 .333,33$ & 74,35 & $872.500,00$ & $3.635 .416,67$ & 68,27 \\
& b. POC & $125.000,00$ & $520.833,33$ & 8,93 & $126.250,00$ & $526.041,67$ & 9,87 \\
3 & Pestisida (Rp) & & & & & \\
& a. Hayati & $105.000,00$ & $437.500,00$ & 7,5 & $104.750,00$ & $436.458,33$ & 8,19 \\
& b. Tricoderma & $30.6625,00$ & $127.604,17$ & 2,18 & $48.750,00$ & $203.125,00$ & 3,81 \\
& c. Corine B & $24.375,00$ & $101.562,50$ & 1,74 & $35.000,00$ & $145.833,33$ & 2,74 \\
& Jumlah & 1.398 .750 & $5.828 .124,99$ & 100 & 1.278 .000 & $5.325 .000,00$ & 100 \\
\hline \hline
\end{tabular}

Sumber : Data yang telah diolah, 2020

Tabel 5. Rata-Rata Biaya Tenaga Kerja Usahatani Padi Organik Varietas Mentik Dan Varietas IR 64 Desa Beji Kecamatan Nguntoronadi Kabupaten Wonogiri

\begin{tabular}{clllllll}
\hline \hline \multirow{2}{*}{ No } & \multirow{2}{*}{ Uraian } & \multicolumn{3}{c}{ Varietas Mentik } & \multicolumn{3}{c}{ Varietas IR 64 } \\
\cline { 2 - 7 } & \multicolumn{1}{c}{ Per UT } & Per Ha & \multicolumn{1}{c}{ Per UT } & Per Ha & $\%$ \\
\hline 1 & Pembajak & $85.000,00$ & $354.166,67$ & 7,58 & $118.250,00$ & $429.708,33$ & 8,95 \\
2 & Pencangkulan & $142.500,00$ & $539.750,00$ & 11,56 & $162.000,00$ & $679.166,67$ & 12,34 \\
3 & Penggaruan & $75.000,00$ & $312.500,00$ & 6,69 & $100.000,00$ & $416.666,67$ & 7,57 \\
4 & Persemaian & $54.750,00$ & $228.125,00$ & 4,89 & $78.250,00$ & $326.041,67$ & 5,92 \\
5 & Penanaman & $177.500,00$ & $739.583,33$ & 15,84 & $194.500,00$ & $810.416,67$ & 14,72 \\
6 & Pemupukan & $77.750,00$ & $323.958,33$ & 6,94 & $77.000,00$ & $320.833,33$ & 5,83 \\
7 & Penyiangan & $149.000,00$ & $620.833,33$ & 13,29 & $169.500,00$ & $706.250,00$ & 12,83 \\
8 & Pengendalian & $65.250,00$ & $217.875,00$ & 4,67 & $76.000,00$ & $316.666,67$ & 5,75 \\
& Hama & & & & & \\
9 & Pemanenan & $192.500,00$ & $802.083,33$ & 17,17 & $210.000,00$ & $875.000,00$ & 15,89 \\
10 & Pengangkutan & $127.500,00$ & $531.250,00$ & 11,37 & $134.500,00$ & $560.416,67$ & 10,18 \\
& Jumlah & $1.146 .750,00$ & $4.6670 .124,99$ & 100 & $1.321 .000,00$ & $5.504 .166,68$ & 100 \\
\hline \hline
\end{tabular}

Sumber : Data yang telah diolah, 2020

Tabel 6. Rata-Rata Biaya Lain-Lain Usahatani Padi Organik Varietas Mentik Dan Varietas IR 64 Desa Beji Kecamatan Nguntoronadi Kabupaten Wonogiri

\begin{tabular}{cclccc}
\hline \multirow{2}{*}{ No } & \multirow{2}{*}{ Uraian } & \multicolumn{2}{c}{ Varietas Mentik } & \multicolumn{2}{c}{ Varietas IR 64 } \\
\cline { 3 - 6 } & \multicolumn{1}{c}{ Per UT } & Per Ha & Per UT & Per Ha \\
\hline 1 & Pajak tanah & $9.575,00$ & $39.895,83$ & $13.450,00$ & $56.041,67$ \\
2 & Perontok Padi & $64.250,00$ & $267.708,33$ & $102.500,00$ & $427.083,33$ \\
3 & Penyusutan alat & & & & \\
& a. Cangkul & $7.250,00$ & $30.208,33$ & $8.000,00$ & $33.333,33$ \\
& b. Sabit & $6.375,00$ & $26.562,50$ & $6.125,00$ & $25.520,83$ \\
& c. Handsprayer & $8.750,00$ & $36.458,33$ & $9.750,00$ & $40.625,00$ \\
& d. Garu & $8.750,00$ & $36.458,33$ & $9.500,00$ & $39.583,33$ \\
& e. Ember & $1.750,00$ & $7.291,67$ & $4.600,00$ & $19.166,67$ \\
& Jumlah & $106.700,00$ & $444.583,32$ & $153.925,00$ & $641.354,16$ \\
\hline \hline
\end{tabular}

Sumber : Data yang telah diolah, 2020

Tabel 7. Rata-Rata Biaya Mengusahakan Usahatani Padi Organik Varietas Mentik Dan Varietas IR 64 Desa Beji Kecamatan Nguntoronadi Kabupaten Wonogiri

\begin{tabular}{lccccc}
\hline \hline \multirow{2}{*}{ No } & \multirow{2}{*}{ Uraian } & \multicolumn{2}{c}{ Varietas Mentik } & \multicolumn{2}{c}{ Varietas IR 64 } \\
\cline { 2 - 5 } & Biaya Sarana Produksi & Per UT & Per Ha & Per UT & Per Ha \\
\hline 1 & $1.398 .750,00$ & $5.828 .124,99$ & $1.278 .000,00$ & $5.325 .000,00$
\end{tabular}


Dewi, et al. 2021

\begin{tabular}{clllll}
\hline \hline 2 & Biaya Tenaga Kerja & $1.146 .750,00$ & $4.670 .124,99$ & $1.321 .000,00$ & $5.504 .166,68$ \\
3 & Biaya Lain-lain & $106.700,00$ & $444.583,32$ & $153.925,00$ & $641.354,16$ \\
& Jumlah & $2.652 .200,00$ & $10.942 .833,3$ & $2.752 .925,00$ & $11.470 .511,84$ \\
\hline \hline
\end{tabular}

Sumber : Data yang telah diolah, 2020

5. Penerimaan Usahatani

Tabel 8. Rata-Rata Penerimaan Usahatani Padi Organik Varietas Mentik Dan Varietas IR 64 Desa Beji Kecamtan Nguntoronadi Kabupaten Wonogiri

\begin{tabular}{llllll}
\hline \hline \multirow{2}{*}{ No } & \multicolumn{1}{c}{ Uraian } & \multicolumn{2}{c}{ Varietas Mentik } & \multicolumn{2}{c}{ Varietas IR 64 } \\
\cline { 2 - 6 } & \multicolumn{1}{c}{ Per UT } & \multicolumn{1}{c}{ Per Ha } & \multicolumn{1}{c}{ Per UT } & \multicolumn{1}{c}{ Per Ha } \\
\hline 1 & Produksi (Kg) & $1.105,5$ & $4.589,59$ & $1.017,5$ & $4.239,59$ \\
2 & Harga (Rp/Kg) & $7.000,00$ & $7.000,00$ & $6.500,00$ & $6.500,00$ \\
3 & Penerimaan (Rp) & $7.710 .500,00$ & $32.127 .083,33$ & $6.613 .750,00$ & $27.557 .291,66$ \\
\hline \hline
\end{tabular}

Sumber : Data yang telah diolah, 2020

6. Pendapatan Usahatani

Tabel 9. Rata-Rata Pendapatan Usahatani Padi Organik Varietas Mentik Dan Varietas IR 64 Desa Beji Kecamatan Nguntoronadi Kabupaten Wonogiri

\begin{tabular}{llllcc}
\hline \multirow{2}{*}{ No } & \multicolumn{2}{|c}{ Uraian } & \multicolumn{2}{c}{ Varietas Mentik } & \multicolumn{2}{c}{ Varietas IR 64 } \\
\cline { 2 - 5 } & & \multicolumn{1}{c}{ Per UT } & Per Ha & Per UT & Per Ha \\
\hline 1 & Penerimaan (Rp) & $7.710 .500,00$ & $32.127 .083,33$ & $6.613 .750,00$ & $27.557 .291,66$ \\
2 & Biaya Mengusahakan (Rp) & $2.652 .200,00$ & $10.942 .833,3$ & $2.752 .925,00$ & $11.470 .511,84$ \\
3 & Pendapatan (Rp) & $5.058 .300,00$ & $21.184 .250,03$ & $3.860 .825,00$ & $10.086 .779,82$ \\
\hline \hline
\end{tabular}

Sumber : Data yang telah diolah, 2020

7. Efisiensi dan Kemanfaatan Usahatani

Tabel 10. Efisiensi Dan Kemanfaatan Usahatani Padi Organik Varietas Mentik Dan Varietas IR 64 Desa Beji Kecamatan Nguntoronadi Kabupaten Wonogiri

\begin{tabular}{llcc}
\hline \hline No & Uraian & Varietas Mentik & \multirow{2}{*}{ Varietas IR 64 } \\
\hline 1 & R/C Ratio & 2,93 & 2,40 \\
2 & Incremental B/C Ratio & & 8,67 \\
\hline \hline
\end{tabular}

Sumber : Data yang telah diolah, 2020

8. Analisis Perbandingan Produktivitas, Pendapatan, dan Efisiensi Usahatani

Tabel 11. Hasil Uji t Produktivitas, Pendapatan, Dan Efisiensi Usahatani Padi Organik Varietas Mentik Dan Varietas IR 64 Desa Beji Kecamatan Nguntoronadi Kabupaten Wonogiri

\begin{tabular}{llllll}
\hline \hline \multirow{2}{*}{ No } & \multicolumn{1}{c}{ Uraian } & \multirow{2}{*}{ Varietas Mentik } & \multicolumn{2}{c}{ Varietas IR 64 } & \multicolumn{2}{c}{ Uji t } \\
\cline { 4 - 6 } & & & & thitung & tabel \\
\hline 1 & Produktivitas $(\mathrm{Kg} / \mathrm{Ha})$ & $4.589,59$ & $4.239,59$ & 12,92 & 2,093 \\
2 & Pendapatan (Rp/Ha/MT) & $21.184 .250,03$ & $16.086 .779,82$ & 3,38 & 2,022 \\
3 & Efisiensi & 2,93 & 2,40 & 5,56 & 2,022 \\
4 & Incremental B/C & & 8,67 & & \\
\hline \hline
\end{tabular}

Sumber : Data yang telah diolah, 2020 